\title{
THE RELIEF PROVIDED TO A COMPLAINANT UNDER SECTION 163(1)(a) OF THE 2008 COMPANIES ACT: AN EXAMINATION OF THE CRITERION WITH REFERENCE TO PEEL $V$ HAMON J\&C ENGINEERING (PTY) LTD
}

\author{
Simphiwe S Bidie \\ LLB LLM LLD \\ Senior Lecturer, Nelson $R$ Mandela School of \\ Law, University of Fort Hare
}

SUMMARY

The remedies in favour of minority shareholders that have developed over the years have been informed by the discriminatory manner in which the proper-plaintiff rule has been applied within the management of companies, in disregard of the rights and interests of minority shareholders. Broadly, section 163(1) of the Companies Act 71 of 2008 accords shareholders or directors of a company three circumstances in which they have rights to apply to court for relief. One ground for application is that an act or omission of a company, or a related person, has had a result that is oppressive or unfairly prejudicial to, or that unfairly disregards the interests of, the applicant. From the contemporary debates and court decisions consulted, it is clear that the criterion that complainants must satisfy under section 163(1) - "any act or omission of the company, or a related person, has had a result", - and the manner in which parties must go about meeting such criterion, is not yet settled. The intention of this paper is to analyse and examine this criterion. The paper seeks to contribute to the debate by using the case of Peel v Hamon J\&C Engineering (Pty) Ltd as the point of reference. The case is pertinent because it touches on all the elements that must be satisfied under section 163(1). Secondly, much as the decision is supported, it seems an error of law was made in one aspect of the decision.

\section{INTRODUCTION}

The remedies in favour of minority shareholders that have developed over the years have been informed by the discriminatory nature in which the proper-plaintiff rule has been applied in disregard of the rights and interests of minority shareholders within the management of companies. ${ }^{1}$ Because

In Foss $v$ Harbottle (1843) 2 Hare 461; 67 ER 189, a claim was lodged in reaction to the majority rule, seeking relief for losses orchestrated by directors of that company. However, 
companies are under the direction of a board of directors, all decisions are their prerogative. At times, however, the board of directors discharges its duties to manage a company's affairs in a manner that is unexpected, and that causes disharmony. ${ }^{2}$ To counter these often-unnecessary occurrences, a scan of various statutes across jurisdictions shows that countries have tended to develop potent remedies in favour of minorities within companies. The Companies Act 71 of 2008 (2008 Act) $)^{3}$ is no exception. It provides a remedy for oppressive and prejudicial conduct under section 163(1). Previously, this remedy was regulated under section 252(1) of the Companies Act 61 of 1973 (1973 Act). In accordance with the remedy's intended purpose, courts have tended to interpret the latter section broadly, depending on the circumstances of the particular case. Looking at the provisions of section 163, it appears that the 2008 Act intended to refine the remedy and make it more accessible to a wider class of persons - that is, not confine it only to shareholders of that company.

Broadly, section 163(1) provides a shareholder or a director of a company with three grounds on which to apply to court for relief. One of these is that an act or omission of the company, or a related person, has had a result that is oppressive or unfairly prejudicial to, or that unfairly disregards the interests of, the applicant. ${ }^{4}$ From the contemporary debates and court decisions consulted, it is clear that the criterion that complainants must satisfy under section 163(1) - "any act or omission of the company, or a related person, has had a result" - and the manner in which parties must go about meeting this criterion, is not yet settled. The intention of this article is to analyse and examine this criterion. The article seeks to contribute to that debate using the case of Peel $v$ Hamon J\&C Engineering (Pty) $L t d^{5}$ as the point of reference. The case is pertinent because it touches on all the elements that must be satisfied under section 163(1). Secondly, much as the decision is supported, an error of law seems to have been made in one aspect of the decision. Under heading 2, the article sets out the legal framework and the criteria to be satisfied by a complainant under section 163(1)(a). Thereafter, under heading 3 , the facts and interpretative context to be observed are

shareholders in the case claimed in their own names, instead of in the name of the company through derivative action. The plaintiffs lost the case on the basis that the claim was lodged in their names rather than in the name of the company, which was the proper plaintiff - hence the "proper plaintiff rule". The money/funds that were fraudulently misappropriated belonged to the company as an incorporated entity and not to the plaintiffs. See also Hand v Dexter 41 Ga. 454, 462 (1871), cited in Thompson "The Shareholder's Cause of Action for Oppression" 1993 The Business Lawyer 699.

2 Thompson 1993 The Business Lawyer 703.

3 GN 421 in GG 32121 of 2009-04-09. It has been amended by the Companies Amendment Act 3 of 2011 (GN 370 in GG 34243 of 2011-04-26).

4 The second ground arises where the business of the company, or a related person, is being or has been carried on or conducted in a manner that is oppressive or unfairly prejudicial to, or that unfairly disregards the interests of, the applicant. Thirdly, where the powers of a director or prescribed officer of a company, or person related to the company, are being or have been exercised in a manner that is oppressive or unfairly prejudicial to, or that unfairly disregards the interests of, the applicant, there is also cause for relief. See $s$ 163(1)(a), (b) and $(c)$ of the 2008 Act; Visser Sitrus (Pty) Ltd $v$ Goede Hoop Sitrus (Pty) Ltd 20145 SA 179 (WCC) par 51; Lazarus Mbethe $v$ United Manganese of Kalahari (Pty) Ltd [2017] ZASCA 67 par 35; Smyth v Investec Bank Ltd [2017] ZASCA 147 par 54; Westerhuis $v$ Whittaker [2018] ZAWCHC 76 par 30.

52013 (2) SA 331 (GSJ). 
tabulated. Heading 4 ventures to unpack in detail the concept "has had". On the other hand, heading 5 seeks to unpack the words "a result". Under heading 6 , there is an examination of the reasoning of the court in Peel. Thereafter, a conclusion is reached under heading 7 .

\section{REGULATORY FRAMEWORK AND THE CRITERIA TO BE SATISFIED}

The relevant wording of section 163(1) of the 2008 Act provides:

"A shareholder or director of a company may apply to a court for relief if- (a) any act or omission of the company, or a related person has had a result that is oppressive or unfairly prejudicial to, or that unfairly disregards the interests of the applicant; ..."

It is plain that five elements must be shown to exist before a court will consider whether other criteria have been adequately satisfied so as to allow the granting of an order in favour of a complainant. Relief may be sought only by (i) "a shareholder or a director" of a company when (ii) "any act or omission" of (iii) "the company, or related person" (iv) "has had" a (v) "result". There is a marked difference in the wording of this section and that of section 994(1) of the UK Companies Act 2006 (UK 2006 Act). As far as it is relevant, the latter section provides that a member of a company may apply to the court by petition for an order on the ground "(b) that an actual or proposed act or omission of the company (including an act or omission on its behalf) is or would be so prejudicial". ${ }^{6}$ This subsection gives a legal right to a member of a company to apply if an (i) "actual or proposed act or omission" of the company, or (ii) an "act or omission on behalf" of the company, is an act or omission that (iii) "is or would be" prejudicial. Under the United States of America's (US) Model Business Corporation Act 1984 (MBCA), corporate powers are exercised by directors. ${ }^{7}$ Section 14.30 of the Act permits a court to order a dissolution of a company if a shareholder has established in an action that directors or those in control of a company "have acted, or are acting, or will act in a manner that is illegal, oppressive or fraudulent". ${ }^{8}$

The focus of this article is on the last two of the five elements of section $163(1)(a)$ - that is, "has had" and a "result". However, practically it is impossible to examine these two elements without necessarily touching on the other elements. This is by virtue of the fact that, under the 2008 Act, these elements are crafted to be umbilically connected to one another. Under section 994(1)(b) of the UK 2006 Act, the comparable wording on the two noted elements in section 163(1)(a) concerns an act or omission that "is or would be so prejudicial". Under the US MBCA, the precise wording is "have acted, or are acting, or will act". Thus, section 14.30(2)(ii) of the MBCA applies to conduct in the past, present and, most importantly, future, as is the case under the UK Act 2006.

$6 \quad S 994(2)$ provides that the provisions of subsection (1) apply to a person who is not a member of a company but to whom shares in the company have been transferred or transmitted by operation of law as they apply to a member of a company.

7 See $\mathrm{s} 8.01(b)$ of the MBCA.

8 See $s$ 14.30(2)(ii) of the MBCA. 


\section{THE FACTS IN PEEL AND THE INTERPRETATIVE CONTEXT}

In the Peel case, the application was based on a number of complaints. The applicants relied on section 163, alleging that an act or omission of Hamon SA and/or Hamon \& Cie had a result that was oppressive and unfairly prejudicial to, or that unfairly disregarded, the interests of the applicants. The claim was based on a sale and transfer agreement and a shareholder's agreement that the parties had entered into during October 2010 to combine their businesses for the benefit of both parties. ${ }^{9}$ As a result, a joint venture was formed between Hamon J\&C/J\&C Engineering and the Hamon respondents under the holdership of Hamon \& Cie (International SA). ${ }^{10}$ The applicants sought an order for relief to sever ties with the Hamon respondents so that Hamon J\&C was no longer associated with Hamon SA and Hamon \& Cie. Pertinently, one of the applicants' contentions was that the Hamon respondents had failed to disclose a material fact, and that such failure (omission) had a result that was oppressive and unfairly prejudicial to their interests and/or unfairly disregarded their interests. The applicants were of the view that non-disclosure by the respondents suggested that they had no regard for their interests. The applicants contended that because they (applicants) had transferred their company (J\&C Engineering) into the joint venture company (Hamon $\mathrm{J} \& \mathrm{C}$ ) with the Hamon respondents so as to have the benefit of Hamon's alleged good name, they should have been advised of all material matters concerning the joint venture company that would affect the company's good name, as well as matters that the respondents should have known had the potential to affect the company's good name.

What the applicants were not aware of was that the respondents, immediately before concluding the joint venture agreement with them, had entered into a Black Economic Empowerment contract with two of their staff members for purposes of attaining an upper BEE score in terms of the BBBEE Act (BEE issue) and to be in line to receive contracts from other government entities. The applicants' view was that they should have been advised about the BEE issue as it had potential to affect the applicants' business in Hamon J\&C and posed serious business risks for the future, even though the BEE issue did not occur in Hamon J\&C, but in Hamon SA. ${ }^{11}$ The applicants viewed the allegations (of fraud in their BEE deal) in a serious light; their take was that if they and their business were to be tainted by the serious allegations, such had a potential to destroy their business prospects going forward. For this reason, the applicants and their business "have been or are" thus exposed to serious business risk. ${ }^{12}$ As a result, the applicants could not continue to work or be associated with the Hamon respondents in a business relationship because the BEE issue had caused an irretrievable breakdown in their relationships owing to mistrust that had

Peel v Hamon J\&C Engineering (Pty) Ltd supra par 8-9.

Peel v Hamon J\&C Engineering (Pty) Ltd supra par 13-15.

Peel $v$ Hamon J\&C Engineering (Pty) Ltd supra par 35-40.

Peel v Hamon J\&C Engineering (Pty) Ltd supra par 46. 
arisen. ${ }^{13}$ The worst part was that the respondents took the attitude that the $\mathrm{BEE}$ issue was of no consequence and as such was not material. ${ }^{14}$

From the provisions of section 163(1), it is evident that the legislature intended to provide a remedy to a specific applicant to challenge an act or omission (occurring through the exercise of powers by a director or prescribed officer of a company or person related to that company) ${ }^{15}$ that "has had" a "result". Thus, as referred to above, the criteria that must be satisfied first are that the applicant be a shareholder or director of that company, and that the conduct of the company "has had" a "result" affecting the applicant adversely. ${ }^{16}$ The words of Moshidi $\mathrm{J}$ in Peel are crucial for those who make an application for relief. The court held that, where the criteria as laid down in section 163(1) have not been satisfied, an applicant would not be granted relief in terms of section 163(2) of the 2008 Act. ${ }^{17}$ When a complaint has been lodged and a court is engaged in the interpretation of the criteria set out, courts begin by interpreting the provisions of that particular section of the Act. ${ }^{18}$

To that end, the approach adopted by Moshidi $\mathrm{J}$ in coming to the Peel decision is relevant to the arguments in this article. The court took the approach that the ambit of the section was not to be constrained such as to inhibit its intended purpose. ${ }^{19}$ One may argue that in respect of section 163 , this approach is notable, and is consistent with section 7 of the 2008 Act, which vividly states the purpose of the Act as including the balancing of the interests of stakeholders. In that context, the provisions of the section 163(1) remedy are unambiguous in their purpose.

Peel v Hamon J\&C Engineering (Pty) Ltd supra par 22.

14 Peel $v$ Hamon J\&C Engineering (Pty) Ltd supra par 40 and 46.

15 Visser Sitrus (Pty) Ltd $v$ Goede Hoop Sitrus (Pty) Ltd supra par 53.

16 Also see in Kudumane Investment Holdings Ltd $v$ Northern Cape Manganese Company (Pty) Ltd [2012] 4 All SA 203 (GSJ) par 49-50; Lewis Group Limited v Woollam (2) [2016] ZAWCHC 162; [2017] 1 All SA 231 (WCC). In Wootliff $v$ Rushton-Turner [2017] EWHC 3129 (Ch) par 57, the court said that the plaintiff had to demonstrate to the satisfaction of the court requirements similar to s 163(1), citing Hawkes v Cuddy (No 2) [2008] B.C.C 390347 , 440; Re Saul D Harrison \& Sons plc [1994] B.C.C.475 499 based on S 994 of the UK Companies Act 2006.

17 Peel v Hamon J\&C Engineering (Pty) Ltd supra par 45; Westerhuis v Whittaker supra par 36 and 46; Louw v Nel 2011 (2) SA 172 (SCA) par 23; Beukes and Swart "Peel v Hamon J\&C Engineering (Pty) Ltd: Ignoring the Result-Requirement of Section 163(1)(a) of the Companies Act and Extending the Oppression Remedy Beyond its Statutorily Intended Reach" 201417 PER/PELJ 1691 1696-1698. See also Count Gotthard SA Pilati v Witfontein Game Farm (Pty) Ltd 20132 All SA 190 (GNP) par 17.

18 Lazarus Mbethe $v$ United Manganese of Kalahari supra par 6.

19 Off-Beat Holiday Club $v$ Sanbonani Holiday Spa Shareblock Limited supra par 27; Donaldson Investments v Anglo-Transvaal Colliers 1979 (3) SA 713 (W) 719; 1980 (4) SA 204 (T) 209. This was so because since section 252 of the 1973 Act was interpreted in previous case law as would advance the remedy rather than to limit its reach, to him, the interpretation of section 163 contemplates that the section should be approached from or be given a broad context as was section 252. Peel v Hamon J\&C Engineering (Pty) Ltd supra par 44 and 52; Donald Investments (Pty) Ltd v Anglo-Transvaal Collieries Ltd: SA Mutual Life Assurance Society Intervening 1979 (3) SA 713 (WLD) $719 \mathrm{H}$, endorsed by full court in Donaldson Investments (Pty) Ltd v Anglo-Transvaal Collieries 1980 (4) SA 204 (T) 709B-F. Also see Smyth v Investec Bank Ltd supra par 20. 


\section{ACT OR OMISSION THAT “HAS HAD”...}

Section 163(1)(a) of the 2008 Act empowers a shareholder or director with standing, as the case may be, to approach a court for an order to protect an interest threatened by an act or omission (occurring through the exercise of power by a director of that company or a related person) that "has had a result". Effectively, the application here is meant to be lodged against the company or a related person/company and not against the directors in person who would have made the decision on behalf of the company. However, looking at the orders that may be issued by a court under section 163(2), an applicant may request, and an order may be granted, by a court to declare as delinquent a director whose conduct or decision was incongruent with the provisions of the Act; or the court may order that the director be placed under probation regardless. Where such an order is applied for, the criteria set out in section 162 of the 2008 Act would have to be satisfied.

Ordinarily, if the language of the provision is read in its proper context and in line with the purpose of the section as a whole, ${ }^{20}$ the wording "has had" suggests that, for a court to rule in favour of an applicant, the conduct complained of (as relates to the element under this criterion) has to have had a result that has affected the complainant's interests. The words are not futuristically framed to read that the conduct "will or would have". The phrasing represents continuous conduct which started in the past but continues to the present informed by the use of the phrase "has had". This phrase indicates that that which occurred in the past is symbiotically connected to the present result, or vice versa. It indicates progression of an occurrence.

It is interesting to note that the wording under section 163(1)(a) of the 2008 Act is different to that under the US MBCA and the UK Act 2006. The latter statutes, in addition to protecting against conduct that occurred in the past and is still persisting, also offer protection or give a right to challenge conduct that might lead to an adverse result in the future. The wording in section 14.30(2)(ii) of the MBCA refers to conduct "in the past, present and future". Under section 994(1)(b) of the UK 2006 Act, reference is made to conduct that "is or would be so prejudicial". Section 163(1)(a) of the 2008 Act does not offer this futuristic directed flexibility to protect one's interest.

\section{ACT OR OMISSION THAT HAS HAD A "RESULT"}

The second phrase that is central to the interpretation of the relief found under section $163(1)(a)$ is "result". Among the criteria to be satisfied under section 163(1)(a), only under one criterion does the word "result" appear. The question then is: in the context of the section, how must a result be determined?

20 Smyth v Investec Bank Ltd supra par 28; Dadoo Ltd v Krugersdorp Municipal Council 1920 AD 530 543; South African Transport and Allied Workers Union v Garvas [2012] ZACC 12; 2013 (1) SA 83 (CC) par 37; and Natal Joint Municipal Pension Fund v Endumeni Municipality [2012] ZASCA 13; 2012 (4) (SCA) 581. 
As alluded to above, the ordinary ${ }^{21}$ meaning of the language of a provision determines the interpretation of that provision. How a "result" must be ascertained is informed by the words "has had". This means that there must have been or there must be an occurrence that will produce or lead to a result at a particular point. At that point, a determination will be made as to what the result is. If the language of the provision is read in its proper context and in line with the purpose of the section as a whole, the word "result" suggests that for a court to rule in favour of an applicant, the conduct complained of has to have had a result affecting the complainant's interests. The result must not be one of no consequence; it must have caused a detriment to the complainant's interests. Thus, practically, it appears that the conduct complained of has to have been complete at the time the complaint is lodged, so that the parties can be in a position to ascertain whether, and/or show, that the conduct has indeed had a result that is adverse to the interests of the complainant.22 If the wording were phrased as in the US MBCA and the UK 2006 Act, one could advance an argument that the wrongful action would not need to be complete, and a completed result would not need to be proved.

Beukes and Swart are in agreement with this submission as they opine that the result and its effect must exist at the time an applicant applies to court. ${ }^{23}$ The authors of Henochsberg on the Companies Act 71 of 2008 support this interpretation as well. They observe that it is the "result" that must be oppressive or unfairly prejudicial, ${ }^{24}$ or that disregards the interests of the applicant - not the act. Thus, for a court to support a complainant, the result complained of (which has had an adverse effect on the interests of that complainant) must have been caused by that act or omission. Therefore, the "present result" requires that the "past-present act or omission" must be a sine qua non for the result. It is submitted that there is nothing within the interpretation of the combined words "has had a result" to suggest a reference to conduct that may or would arise in future. ${ }^{25}$ This is unlike the wording under the US MBCA and the UK 2006 Act where future development of a prejudicial conduct is apparently anticipated.

A practical understanding of whether a result has eventuated, and how this criterion must be satisfied, may be gleaned through the lens of what occurred in Peel. In summary, what the applicants argued for in Peel can be reduced to three factors. First, they alleged that the Hamon respondents failed to disclose a material fact, or to remedy the non-disclosure of that fact, immediately after the parties entered into the agreement in question. Secondly, the applicants had a legitimate expectation that they would profit from being associated with the name Hamon, but, because of the actions of the Hamon respondents, they did not and could no longer do so. Thirdly,

\footnotetext{
Ibid.

22 Peel v Hamon J\&C Engineering (Pty) Ltd supra par 47; Delport, Fourie, Vorster, Burdette, Esser, and Lombard Henochsberg on the Companies Act 71 of 2008 (2021) 574(2).

3 Beukes and Swart 2014 PER/PELJ 1704.

24 Delport et al Henochsberg on the Companies Act 71 of 2008597.

25 Under s 163(1) the words "any actual or proposed act or omission of the company (including an act or omission on its behalf) is or would be so prejudicial", which appear under s 994 of the UK Companies Act, do not appear. The words "would be so prejudicial" appear to refer to future conduct.
} 
their company was exposed to serious business risks as a result of the conduct of the Hamon respondents. ${ }^{26}$ The question that then arose was whether a "result" had eventuated as contemplated under the first criterion in section $163(1)(a)$ ?

One of the respondents' contentions was that the conduct complained of occurred in the past and so was irrelevant to the applicants. ${ }^{27}$ Moshidi $\mathrm{J}$ held that the complaint of the applicants fell squarely under section 163 of the 2008 Act. ${ }^{28}$ The judge regarded the argument presented by the respondents to be contrary to the express provisions of section 163(1). In his analysis, he reasoned that the section covers both "past and future" conduct. ${ }^{29}$ After listing all the criteria that must be satisfied, the court held that section $163(1)(a)$ was designed such that it applies to past conduct even when such conduct is no longer persisted with. Therefore, in the context of the Hamon respondents' conduct, the court found the section to be applicable and the conduct to comprise sufficient ground to invoke the provisions of the section. On the basis presented, the respondents' arguments were found to be without merit. ${ }^{30}$ What was not certain or clear in the court's reasoning was what he meant when he referred to "future conduct". This point is ventilated below.

The court went on to determine another contention that - since the BEE issue was still under investigation by the department - the applicants could not argue that a risk had eventuated because, at the time, their concerns were still speculative. Their risk would materialise once it was found from the investigation undertaken by the department that the BEE deal was indeed a sham. On this argument, the court's view was that when a matter is already under investigation, there can hardly be a question of speculation. ${ }^{31}$ The court was suggesting that if a matter is a subject of investigation, then it is only fair and reasonable to conclude that a result has eventuated, or that an accommodative interpretation can be adopted as if a result had eventuated.

26 They then sought an order directing: an exchange of shares between the parties in terms of section $163(2)(e)$; the restoration of Hamon SA by the applicant of a part, alternatively, the whole of the consideration that Hamon SA paid for the shares, with conditions as envisaged in section $163(2)(g)$; the varying or setting aside of the sale of shares transaction between Hamon SA, the second applicant and Hamon J\&C and compensating Hamon J\&C and/or second applicant, or any other of the applicants as envisaged in section 163(2)( $h)$; and that Hamon SA pay compensation to the second applicant and/or Hamon J\&C as envisaged in section 163(2)(j). Peel v Hamon J\&C Engineering (Pty) Ltd supra par 23. It is submitted that there is no doubt that relief in respect of the complaints raised by the applicants in Pee could be ordered by a court under section 163(2) of the 2008 Act. This is notwithstanding that the orders requested could have been prayed for under other sections of the 2008 Act. Thus, insofar as entertaining and granting of the orders was concerned, the court did not err.

27 Peel v Hamon J\&C Engineering (Pty) Ltd supra par 61.

28 Peel $v$ Hamon J\&C Engineering (Pty) Ltd supra par 62.

29 Peel $v$ Hamon J\&C Engineering (Pty) Ltd supra par 61.

30 Ibid.

31 Peel v Hamon J\&C Engineering (Pty) Ltd supra par 62. 


\section{EXAMINATION OF THE REASONING IN PEEL}

With the aforegoing background in mind, as well as the arguments and the views expressed by Moshidi $J$, the question is whether the approach adopted by the court was reasonable in the circumstances of the case?

The court appears to have interpreted the words "has had a result" too broadly. It held that the words allowed for relief for conduct "in the past" as well as "in the future". ${ }^{32}$ If this interpretative approach means that section 163(1)(a) also applies in the future, it is submitted that the court erred insofar as it included the phrase "in the future". By including these words, the court's interpretation suggests that it would be acceptable to interpret the section, in a claim relying on conduct that "has had" a result (which suggests pastpresent conduct), as including in its ambit an act or omission that would have a result - that is, conduct that would still lead to a result. It is submitted that, in line with the argument presented earlier, including a "would have" future result as Moshidi J's interpretation seems to suggest, is an overly broad interpretation in line with the arguments presented by the respondents, which he dismissed. If that is indeed what Moshidi $\mathrm{J}$ meant, it is submitted that his interpretation constitutes an overreach. The interpretation amounts to an importation of words into the criterion. The words do not seem to have been in contemplation when the drafters of section 163(1)(a) crafted the criterion to refer to an act or omission that had already reaped its result, and they could not have been unaware of the provisions of section 994(1) of the UK 2006 Act, which uses the words "would be so prejudicial" within its provisions. Clearly, that section of the phrase "would be so prejudiced" signifies reference to an anticipated future result that is adverse to the interests of a member or that company.

Another angle from which the court's decision can be viewed is to ask whether it was referring to conduct (and the ensuing result) that occurred prior to entering into the contractual arrangement but that could fall to be addressed after entering into that arrangement. From the context of paragraph 61 of the judgment, it appears that the court seems to have meant that relief can be sought by a person even if the conduct was only discovered at a later stage. Section 163(1) could be invoked not only when conduct produced a result in that moment. Even if the conduct occurred at a time in the past, it could still be challenged in the present-future time. Approached from this angle, it does not appear that the court meant that the section applies even to conduct that has yet to produce a result in the future. Looked at closely, it appears that when the court made its decision, it had in mind section 219(1) of the 2008 Act, relating to continuous conduct. This is despite the fact that at the time, there was no legal obligation between the parties, or a duty to negotiate in good faith by each of the parties. ${ }^{33}$

Assuming that there was overreach, the court nevertheless, after citing the principles applicable to the provisions of section 163(1) and various other

32 Peel v Hamon J\&C Engineering (Pty) Ltd supra par 61.

33 For a discussion of the concept of continuous practice, see Bidie "A Reflection on the Interpretation Germane to an 'Act or Omission' or 'Course of Conduct or Continued Practice' in terms of the 2008 Companies Act: A Critical Analysis of Singh v The CIPC" 202034 Spec Juris 1. 
provisions of the section showing its broad nature, ${ }^{34}$ correctly concluded that it was clear that the BEE transaction that formed the substance of the complaint was inappropriate. It held that the fact that the Hamon respondents "did not take" steps to remedy their conduct was oppressive to the interests of the applicants. ${ }^{35}$ The words the court used to express itself are "were and are exposed" to serious business risks (suggesting that there was a "result"). This would be so especially if the DTI in its investigation were to find that the whole BEE deal was a sham. ${ }^{36}$ Notwithstanding the divergent arguments presented above, when one considers the words used by the court ("was and is" and "disregards or disregarded"), 37 it is interesting that, when referring to the words "has had a result", they were interpreted as being capable of applying to an act or omission in the "past-present" as well as "in the future". In selecting the words, "was and is" and "disregards or disregarded", it appears that the court did realise that a result had to be connected to an act or omission that "is being or has already" been committed and now has produced a particular adverse/detrimental eventuality. It is thus interesting that the court stated that the words "has had" were capable of an interpretation encompassing an act or omission yet to occur in the future.

Writing a paper in reference to the case, Beukes and Swart argued that the applicants should not have been successful in Peel. First, this was so because the conduct complained of had not been completed by the time the joint venture company was incorporated and the applicants became shareholders of Hamon J\&C. ${ }^{38}$ By the same token, they further argued that, in their opinion, the applicants should have used a remedy from the law of contract in the form of restitutio in integrum, rather than section 163 as they seemed to argue for misrepresentation and as such should not have been successful in terms of the section. ${ }^{39}$ In the alternative, section 165 of the 2008 Act (derivative action) would have been more suitable. ${ }^{40}$ Furthermore, the authors disagreed with the decision in Peel with respect to when a business risk had to be taken to have eventuated. According to them, "a potential serious business risk" was not a result that satisfied the requirement of "result" under section 163(1) because the risk had not eventuated at the time of the application; the result was still a possibility that may or may not occur. ${ }^{41}$ Because the court held that the applicants "were and are exposed to serious business risks especially if the DTI eventually finds that the whole BEE issue was a sham", ${ }^{42}$ Beukes and Swart are of the view that the court did not in fact find that the applicants "were exposed" to a serious business risk, but only that they would be exposed to a serious business risk if the DTI eventually found that the BEE transaction was

$34 \mathrm{He}$ also referred to other foreign jurisdictions and penned the purpose of Broad-Based Black Economic Empowerment (B-BBEE).

35 Peel v Hamon J\&C Engineering (Pty) Ltd supra par 55.

36 Peel v Hamon J\&C Engineering (Pty) Ltd supra par 46.

Peel v Hamon J\&C Engineering (Pty) Ltd supra par 55.

Beukes and Swart 2014 PER/PELJ 1700.

Beukes and Swart 2014 PER/PELJ 1701

Beukes and Swart 2014 PER/PELJ 1704

Beukes and Swart 2014 PER/PELJ 1702-1703.

Peel v Hamon J\&C Engineering (Pty) Ltd supra par 55. 
improper. ${ }^{43}$ That view was fortified in their observation that the court did not specifically indicate that the exposure constituted prejudice, oppression or a disregard of the applicants' interests. Therefore, the implication of the decision was that not only would a serious business risk be a result that satisfies the requirements of section 163(1)(a), but that the same would also be true for the mere possibility of a serious business risk. ${ }^{44}$

It is submitted that there is a preferred alternative to the understanding proffered by Beukes and Swart. First, it is important to clarify that there existed a contract between the parties to merge their companies. The terms of that contract were not infringed by any party at the time the application in terms of section 163 had been instituted, so the contract and its terms were not in contention. ${ }^{45}$ From reading the case, what turned out to be the point of contention was something that was not contemplated by the parties in their contract, being the "BEE issue", which was viewed by the applicants as serious enough to have an adverse effect on their interests. ${ }^{46}$ Thus it was something the applicants as party to the contract felt had a bearing on the credibility of the relationship created through the contract, such that it "had seriously affected/impaired" and "would continue to affect/impair" the parties' business relationship moving forward. To put the arguments into perspective, according to the first argument by the applicants, the second and third respondents engaged in an inappropriate BEE exercise, and they did not and had not sought to take appropriate measures to remedy their conduct. ${ }^{47}$ They transacted with November and Mangwana and did not disclose this fact. As a result, the applicants "were and are exposed" to serious business risks. ${ }^{48}$ This would be especially so if the DTI were to eventually find that the whole BEE issue was a sham. ${ }^{49}$ The arguments in the case thus centred on two factors: "respondent's failure to disclose"; and the fact that the applicants "were and are exposed". In hindsight, the argument meant that disclosure did not occur when reasonable complainants would expect that it should have, and as held by Moshidi $\mathrm{J}$, evidence proved this to be so. ${ }^{50}$ The complainants felt that their interests at the time had been undermined by the non-disclosure and that the conduct of undermining continued well after the parties had entered into their business relationship. Because, in law, a failure to disclose is characterised as an omission, it is not clear why the court was wrong, as Beukes and Swart aver, to regard the non-disclosure by the Hamon respondents as a "result" that had affected the interests of the applicants. It is clear in the judgment that Moshidi $\mathrm{J}$ was convinced that a result had eventuated by the use of the

43 Beukes and Swart 2014 PER/PELJ 1703.

44 Ibid.

45 Starting the analysis of the case in Wootliff $v$ Rushton-Turner supra, Chief Registrar Briggs made a similar observation that the petition in the case did not allege breach of any of the agreements regulating the affairs of the company in question, and the case was not carried out on those bases.

46 Peel $v$ Hamon J\&C Engineering (Pty) Ltd supra par 57.

47 Peel v Hamon J\&C Engineering (Pty) Ltd supra par 55.

48 Ibid.

49 Ibid.

50 Ibid 
words "were and are exposed" to "business risks" as this was the underlying argument by the applicants. ${ }^{51}$

Developing from the first argument, in their second, the applicants averred that they had "legitimate expectations to profit" from their association with the Hamon company/respondents. Because of the respondent's conduct, there existed a clear chance that they would no longer profit, or the chance that they would was close to nil. According to the court, the presented evidence proved this to be so - a "result" had eventuated. The result was that the applicants would no longer derive benefits from their association with the name "Hamon" as they had legitimately expected. The actions of the Hamon respondents with regard to the BEE issue had made such procurement impossible.

Lastly, the applicants asserted that the resondents' conduct (the BEE issue) caused their company to be exposed to business risks. The fact that the company's business was exposed to risks, and that this was accepted by the court as having been evidently proved, constituted "a result". The result is that the "company's business was exposed due to the BEE issue". The conduct of exposing their business to risks was complete and the result was "exposure to risks". In this regard, the DTI did not need to complete its investigation to establish the extent of the risk of exposure. The fact is there was exposure at that time. This exposure was given impetus by the fact that the respondents admitted that the BEE transaction was not in line with the law. The risk here was that the companies associated with Hamon would no longer be eligible to be considered for business contracts by state entities. This was especially so given that the Hamon respondents had acknowledged that the BEE transaction was not in line with the B-BBEE Act with which they had to comply. The exposure was factually proved notwithstanding that the complaint was phrased in arguments as if the risk were still a possibility, instead of it being real at the time.

\section{CONCLUSION}

The aforegoing discussion centres on a liberal interpretation of the criterion under section 163(1)(a) of the 2008 Act, and on whether that interpretation is consistent with the overall purpose - first, of the section as a whole, and secondly, of the 2008 Act generally. It is the writer's considered view that Moshidi J's approach in the case aligns well with the general purpose of the Act and that it may be interpreted as one that fosters a liberal interpretative approach to strengthen observance of corporate governance, as intended by the drafters of the Act.

Further, the writer is of the view that the applicants' argument in Pee/ with regard to the BEE issue (that it had potential to affect the company's business) must not be read literally or strictly to mean that a business risk had not materialised at the time. The term "materialised" in the context of the

51 Moshidi J defined "business risk" as: "The probability of loss inherent in organisations operations and environment (such as competition and adverse economic conditions) that may impair its ability to provide returns on investment. Business risks plus the financial risk arising from the use of debt (borrowed capital and/or trade credit) equal to corporate risk" Peel v Hamon J\&C Engineering (Pty) Ltd supra par 55. 
facts of the case must be given a flexible meaning so as to assist in curbing conduct of the nature seen in Peel; otherwise, if interpreted strictly, courts would be running the risk of allowing company directors breathing space to circumvent corporate governance rules. The argument must be understood to mean that, at the conclusion of the joint venture company, it should have, or it ought to have occurred in the minds of the Hamon respondents that their failure to disclose the BEE issue to the applicants was accompanied by the knowledge that it was a contract that was legally impermissible and wrong. It therefore ought to have occurred to them that on discovery that the BEE issue was indeed a sham, the interests of the applicants would be detrimentally affected, as the sham was not only a crime, but was also conduct that would shutter business opportunities. It is submitted that this is how the court's argument has to be understood. Based on the presented evidence, there is no doubt that the Hamon respondents knew that the BEE contract was a sham. Moshidi $\mathrm{J}$ established this from the evidence, as well as from the respondents, who themselves confirmed that they knew it was impermissible. Moshidi $\mathrm{J}$ pointed out from their answering affidavit that the respondents conceded that the contracts with the two ladies did not comply with the requirements of the B-BBEE Act. ${ }^{52}$ Thus, it is submitted in support of the court's decision, that in ruling for the applicants, it recognised that in all scenarios the actions or omissions of the Hamon respondents had to be interpreted as having had a result that could be interpreted as having eventuated. This decision closes any potential loopholes within section 163(1)(a) of the 2008 Act that company directors are likely to and/or would be likely to explore as a means not to be held accountable for their actions.

52 Peel v Hamon J\&C Engineering (Pty) Ltd supra par 63. 